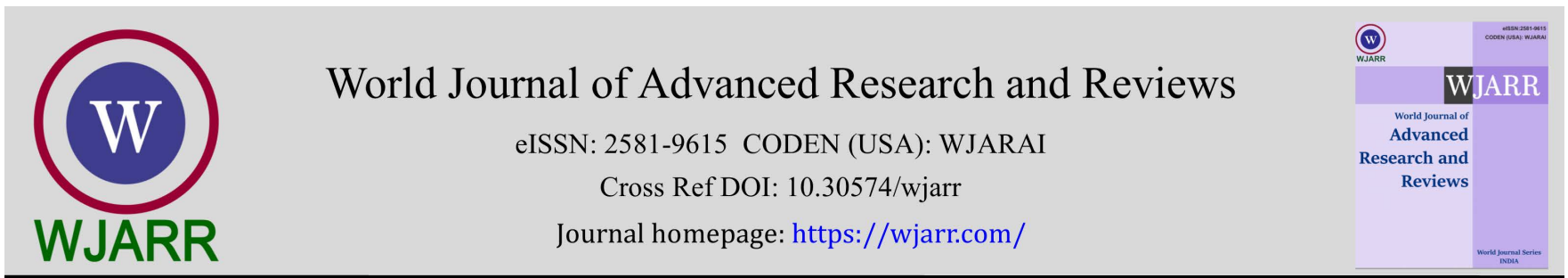

(CASE REPORT)

\title{
Longitudinal extensive transverse myelitis with sixth nerve palsy post ChAdOx1 nCov-19 vaccine: A case report and literature review
}

\author{
Abed AlRaouf Kawtharani 1, Battoul Fakhry 1, ${ }^{*}$ and Abbass Serhan ${ }^{2}$ \\ ${ }^{1}$ Department of internal medicine, faculty of medical sciences, Lebanese University, Beirut, Lebanon. \\ 2 Department of internal medicine, Secours Populaire Libanais, Lebanon.
}

World Journal of Advanced Research and Reviews, 2021, 12(02), 526-538

Publication history: Received on 14 October 2021; revised on 22 November 2021; accepted on 24 November 2021

Article DOI: https://doi.org/10.30574/wjarr.2021.12.2.0613

\begin{abstract}
Concurrently with the quick development of COVID-19 vaccines globally, concerns about vaccination efficacy and safety are rising. Neurological complications such as transverse myelitis (TM) are major worries because they can cause lifelong disabilities, which may require long term care. Here, we report a case of longitudinal extensive transverse myelitis (LETM), with sixth nerve palsy in a young female occurring shortly after ChAdOx1 nCov-19 vaccine. The patient recalled developing strabismus, progressive ascending bilateral lower limb weakness, along with upper extremity paresthesia, abnormal sensation below T6 dermatomes, and difficulty in urination. She presented to the hospital with complete paralysis below the neck associated with urinary retention. Extensive diagnostic studies were performed to rule out alternative etiologies, including but not limited to demyelinating diseases, para-post infectious agents, paraneoplastic syndromes, tumors, and autoimmune diseases. She was treated with corticosteroids and discharged upon clinical improvement. However, the patient clinically deteriorated and intravenous immunoglobulin was administered. Unfortunately, the patient is still suffering from physical impairment. We suggested that LETM could be induced by an autoimmune process triggered molecule mimicry. In conclusion, safety monitoring of the COVID-19 vaccines is of great importance in the post marketing surveillance, particularly for rare adverse events.
\end{abstract}

Keywords: COVID-19; SARS-CoV-2; Vaccine; Adverse event; Acute transverse myelitis; Abducens nerve palsy

\section{Introduction}

Transverse myelitis (TM) is a very rare disease with an incidence of 3 per 100,000 patients years [1]. It causes motor, sensory, and autonomic dysfunction due to a focal or extensive inflammation in the spinal cord [1]. Common causes include infectious agents and demyelinating illnesses, and around 30\% of cases are of unknown etiology [2]. TM after vaccination is even a rarer entity that was reported in 37 cases between 1970 and 2009 with the majority appearing during the first month after vaccines, such as hepatitis B, measles mumps rubella (MMR), and influenza immunizations [3]. Similarly, newly emerged Coronavirus disease 2019 (COVID-19) vaccines were reported to be associated with TM. According to ANA investigates, 9 cases over 51,755,477 vaccinated individuals suffered from TM, [4] and a recent published review by Garg et al, [5] delineated 7 cases of TM post COVID-19 vaccines found in the literature.

Palsy of sixth (abducens) cranial nerve results in strabismus due to abduction deficit. It is usually precipitated by microvascular diseases or tumors and less likely vaccines [6]. Neurological adverse events of COVID-19 vaccines encompass abducens nerve palsy as shown in a previous report [7]. However, to our knowledge, there is no reported cases of TM jointly with abducens nerve palsy post-COVID-19 vaccination. Thus, herein, we present a case of longitudinal extensive transverse myelitis (LETM) and sixth nerve palsy seen in a previously healthy young woman after receiving ChAdOx1 nCov-19 vaccine.

\footnotetext{
${ }^{*}$ Corresponding author: Battoul Fakhry

Department of internal medicine, faculty of medical sciences, Lebanese University, Beirut, Lebanon.

Copyright (C) 2021 Author(s) retain the copyright of this article. This article is published under the terms of the Creative Commons Attribution Liscense 4.0.
} 


\section{Case details}

\subsection{Clinical presentation}

A 37 years old previously healthy female admitted to our hospital 4 weeks after her first dose of ChAdOx1 nCov-19 vaccine complaining of complete paralysis below the neck (quadriplegia) associated with urinary retention.

\subsection{Patient's history}

Patient reported having fever on the $2^{\text {nd }}$ day following vaccination that lasted for 12 days. Few days after her shot, the patient also developed left eye esotropia accompanied by decreased visual acuity. She was diagnosed with abducens nerve palsy for which she received vitamin B12 and modified her eyeglasses. The strabismus resolved within 2 weeks. Concomitantly, the patient started having lower back pain that increased in intensity with days, along with upper extremities paresthesia and progressive ascending lower limbs weakness, which caused her gait disturbance and multiple falling down. She remarked that her symptoms were more prominent on the left side of her body. In addition, she complained of an abnormal sensation below T6 dermatomes and difficulty in urination. She started then physiotherapy without physician referral, however, her condition got worse over the days, so she consulted a neurologist. At that time she was no longer ambulatory. Figure 1 summarizes clinical presentation of the patient.

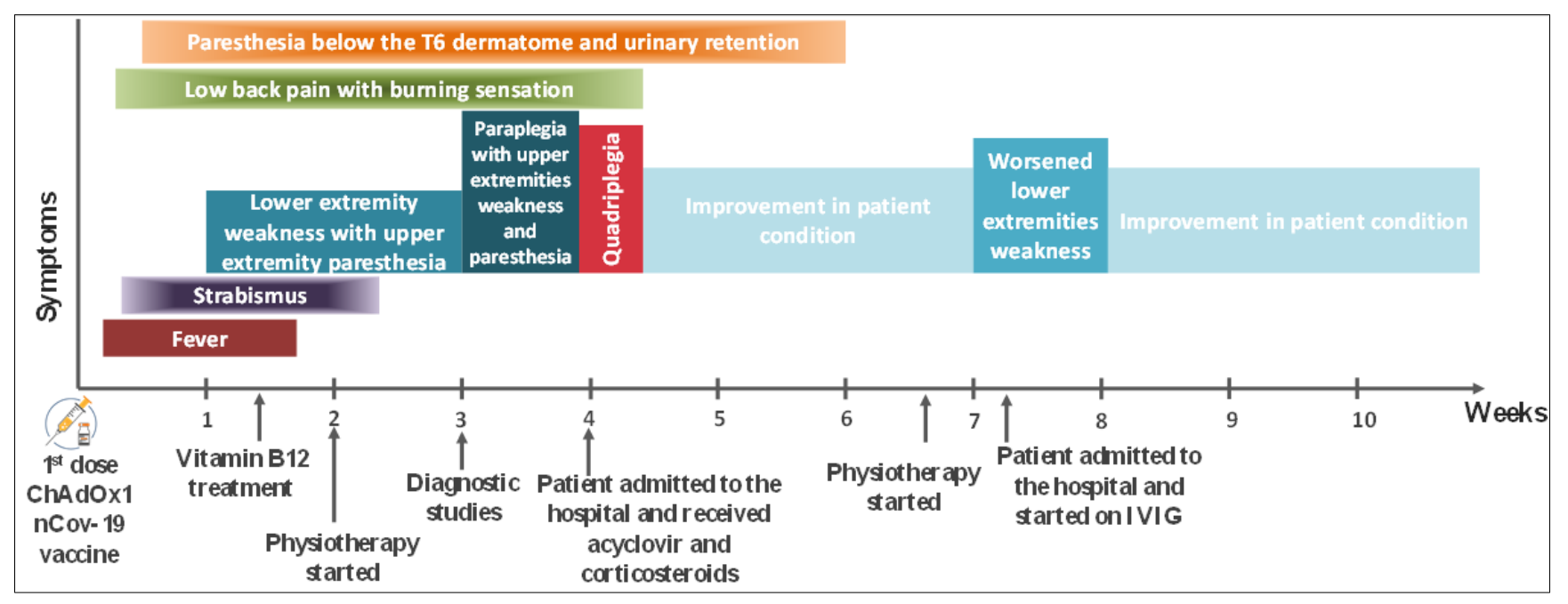

Figure 1 Clinical course and treatment timeline

\subsection{Investigation}

On admission, patient was afebrile and her vitals were within normal ranges. Patient denied having headaches, vertigo, neck rigidity, nausea, vomiting, or difficulty swallowing. Physical exam revealed diffusely inhibited deep tendon reflex, lack of proprioceptive, pain and light touch sensation below T6 dermatome, and motor strength grade of $0 / 5$ in the lower limb and 1/5 in the upper limb, according to medical research council.

Blood investigation, renal and liver function test were normal, except for an elevated CRP level of $8 \mathrm{mg} / \mathrm{L}$. Real time polymerase chain reaction (RT-PCR) of a nasopharyngeal swab testing Sever Acute Respiratory Syndrome Coronavirus 2 (SARS-CoV-2) RNA was negative. Cerebrospinal fluid analysis showed mild pleocytosis $35 / \mu$, high RBC, normal protein and glucose levels, and no growth was obtained from CSF. Viral disease of the central nervous system was ruled out by RT-PCR for 9 DNA and RNA neurotropic viruses. Mycobacterium tuberculosis and nontuberculous mycobacterium RT-PCR turned negative. Serum anti-aquaporin 4 antibodies were negative as well. All laboratory parameters are summarized in Table 1.

Electromyography (EMG) and nerve conduction studies were in favor of moderate bilateral neuropathy of the lower limb. There was no abnormal findings on the EMG of the upper limbs. Neuroimaging of the brain and the spine using magnetic resonance imaging (MRI) was performed with and without contrast. Brain MRI turned normal with no postcontrast enhancement, (Figure 2) while spine MRI demonstrated cervical and dorsal cord swelling with extensive 
intramedullary signal hyper-intensity on T2-weighted and Stir images at C1 to C6 levels, and D1 to D7 levels involving the entire diameter of the cord without contrast enhancement.(Figure 3\&4).

Table 1 Summary of laboratory parameters of the patient

\begin{tabular}{|c|c|c|}
\hline Laboratory parameters & Value & Reference range \\
\hline \multicolumn{3}{|l|}{ Hematology } \\
\hline $\mathrm{WBC} \times 10^{9} / \mathrm{L}$ & 7.4 & $4.5-10.5$ \\
\hline Neutrophils \% & 75 & $43-76$ \\
\hline Lymphocytes \% & 18 & $17-48$ \\
\hline Monocytes \% & 8 & $0-10$ \\
\hline Eosinophils \% & 1 & $0-10$ \\
\hline Basophiles \% & 0 & $0-2$ \\
\hline $\mathrm{RBC} \times 10^{12} / \mathrm{L}$ & 4.89 & $3.8-5.8$ \\
\hline Hemoglobin g/dl & 13 & $12-16$ \\
\hline Hematocrit \% & 43 & $36-48$ \\
\hline MCV fL & 83.6 & $80-93$ \\
\hline MCH pg & 27 & $26-32$ \\
\hline $\mathrm{MCHC}$ g/dl & 32.3 & $31-35$ \\
\hline Platelets $\times 10^{9} / \mathrm{L}$ & 330 & $150-450$ \\
\hline \multicolumn{3}{|l|}{ Coagulation } \\
\hline PT sec & 13.3 & 13.2 \\
\hline PT activity $\%$ & 85 & $70-100$ \\
\hline INR & 1.00 & \\
\hline \multicolumn{3}{|l|}{ Chemistry } \\
\hline Glucose mg/dL & 92 & $76-100$ \\
\hline Urea mg/dL & 17 & $6-24$ \\
\hline Creatinine $\mathrm{mg} / \mathrm{dL}$ & 0.8 & $0.5-1.35$ \\
\hline SGOT U/L & 26 & $<35$ \\
\hline Alkaline phosphatase U/L & 67 & $44-147$ \\
\hline Sodium $\mathrm{mEq} / \mathrm{L}$ & 136 & $135-145$ \\
\hline Potassium mEq/L & 4.1 & $3.5-5.5$ \\
\hline Chloride $\mathrm{mEq} / \mathrm{L}$ & 104 & $100-108$ \\
\hline \multicolumn{3}{|l|}{ Lipid panel } \\
\hline Cholesterol mg/dL & 191 & Desirable $<200$ \\
\hline HDL mg/dL & 64 & Desirable $>60$ \\
\hline Triglyceride $\mathrm{mg} / \mathrm{dL}$ & 89 & Desirable $<150$ \\
\hline LDL mg/dL & 75 & Desirable $<130$ \\
\hline \multicolumn{3}{|l|}{ Serology } \\
\hline CRP mg/L & $8^{*}$ & $0.8-1.0$ \\
\hline \multirow{2}{*}{ CMV IgM } & \multirow{2}{*}{0.20} & Negative $<0.70$ \\
\hline & & Positive $>=0.9$ \\
\hline \multicolumn{3}{|l|}{ Endocrinology } \\
\hline Procalcitonin ng/ml & $<0.1$ & $0.0-05$ \\
\hline \multicolumn{3}{|c|}{ C.S.F. } \\
\hline $\mathrm{RBC} / \mu \mathrm{l}$ & $2750^{*}$ & Adult: $0-10$ \\
\hline
\end{tabular}




\begin{tabular}{|l|c|c|}
\hline WBC $/ \mu \mathrm{l}$ & 35 & Adult:0-5 \\
\hline Protein $\mathrm{mg} / \mathrm{dl}$ & 25 & $0-6$ days:70 \\
\hline Glucose mg/dl & 87 & $\begin{array}{c}60-70 \% \text { of } \\
\text { glycemia }\end{array}$ \\
\hline Culture CSF & $\begin{array}{c}\text { No growth after } 48 \\
\text { h }\end{array}$ & \\
\hline Neuro9 Viral Panel by Real-time PCR in CSF & \\
\hline Adenovirus & Negative & \\
\hline Cytomegalovirus & Negative & \\
\hline Epstein-Barr Virus & Negative & \\
\hline Herpes Simplex Virus 1 & Negative & \\
\hline Herpes Simplex Virus 2 & Negative & \\
\hline Varicella-Zoster Virus & Negative & \\
\hline Enterovirus & Negative & \\
\hline Parechovirus & Negative & \\
\hline Human Herpes Virus 6 & Negative & \\
\hline Human Herpes Virus 7 & Negative & \\
\hline Parvovirus B19 & Negative & \\
\hline Detection of Tuberculosis DNA by Real-time PCR in CSF \\
\hline MTB & Negative & \\
\hline NTM & Negative & \\
\hline Immunology & <1/10 & Negative:<1/10 \\
\hline $\begin{array}{l}\text { Aquaporin4 (neuromyelitis optica } \\
\text { NMO) CSF IgG antibodies detected by } \\
\text { I.F. }\end{array}$ & \\
\hline
\end{tabular}

CRP: C -reactive protein; CSF: Cerebrospinal fluid; INR: International Normalized Ratio; MCH: Mean Corpuscular Hemoglobin; MCHC: Mean Corpuscular Hemoglobin Concentration; MCV: Mean Corpuscular Volume; MTB: Mycobacterium Tuberculosis; NTM: Non Tuberculous Mycobacteria; RBC: Red Blood Cell; WBC: White Blood Cell
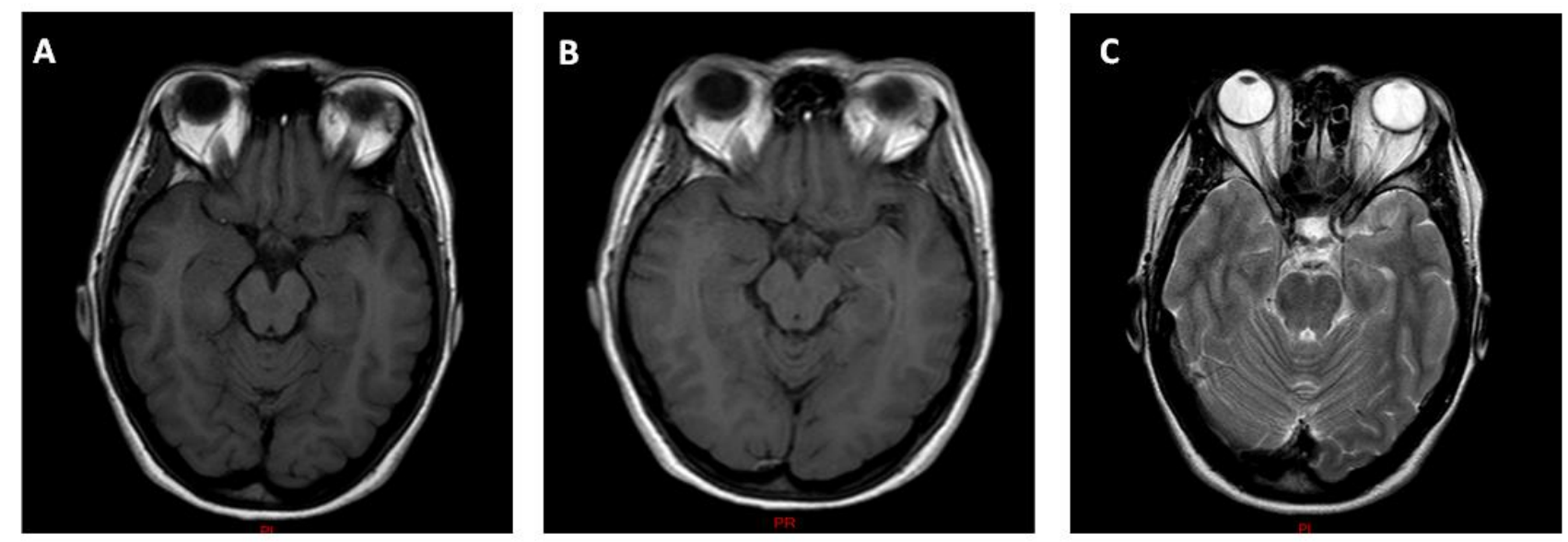

Figure 2 T1-weight (A), T1-weight with contrast (B), and T2-weight (C) magnetic resonance imaging (MRI) scan of the brain showing no abnormal findings and no uptake of the contrast 


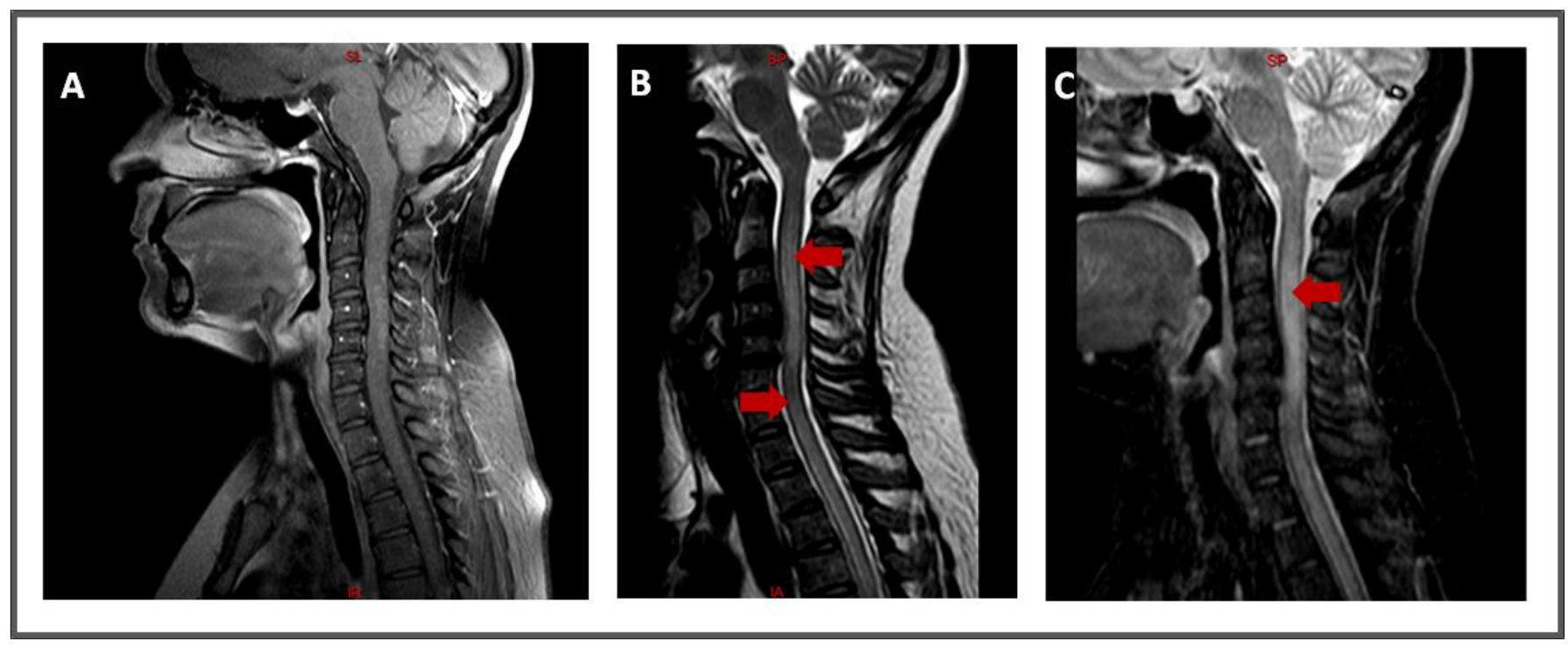

Figure 3 Sagittal Cervical T1-weight with contrast (A), cervical and dorsal T2-weight (B), and cervical Stir (C) MRI of the spine showing spinal cord swelling at cervical and dorsal levels (arrows). We noted narrowed anterior and posterior subarachnoid spaces secondary to intramedullary signal hyper-intensity on T2 (B) and Stir (C) at C1-C6 levels, and T1T7 levels with no post contrast enhancement changes. Disc diseases can be noted at C4-C5 and C5-C6 can be noted.

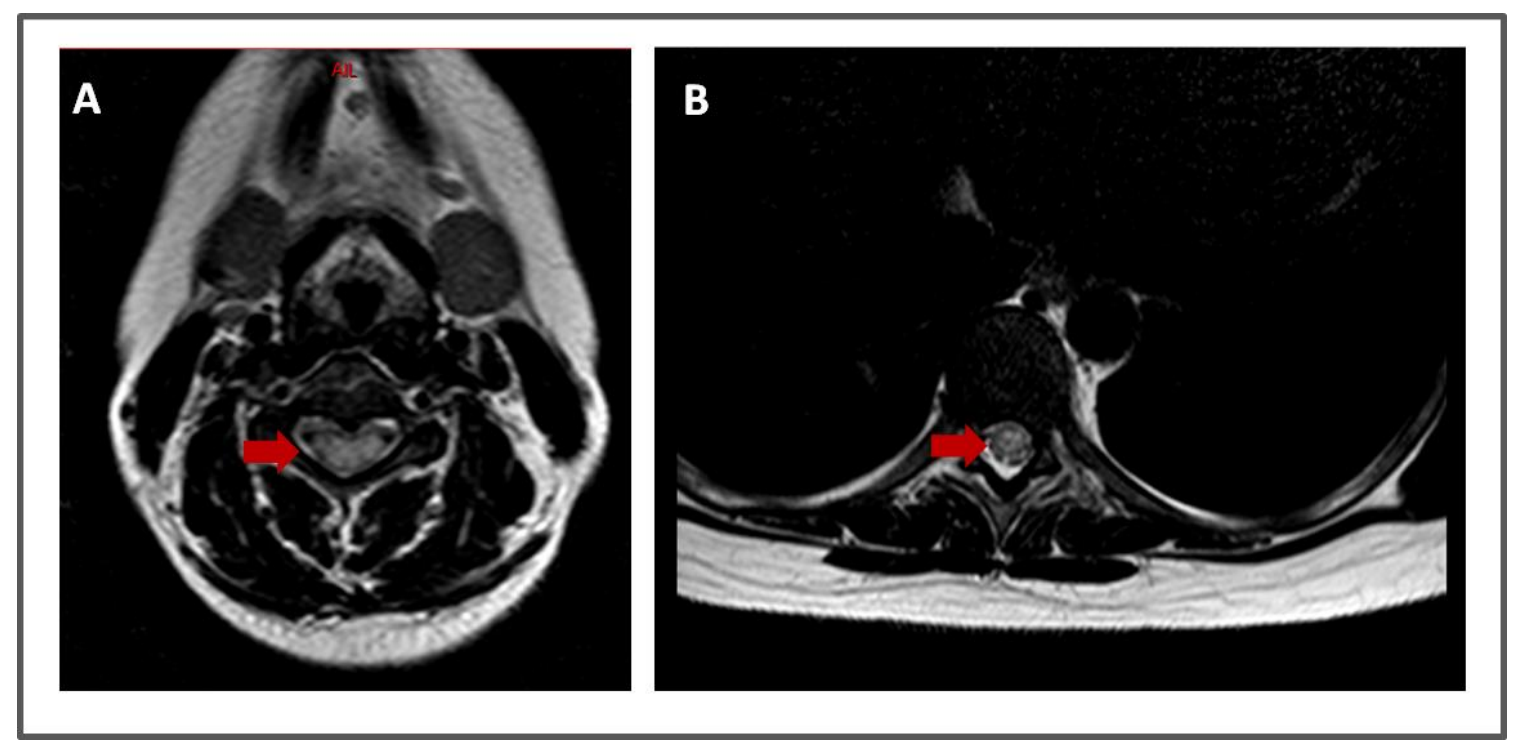

Figure 4 Cervical axial (A) and dorsal axial (B) T2-weighted images showing extensive hyper-intensity (arrows) reflecting a total transverse involvement of the diameter of the cord

\subsection{Differential diagnosis}

In this context of acute onset of progressive ascending paralysis associated with hypoesthesia and esotropia, a differential of Guillain-Barré syndrome, neuromyelitis optica, multiple sclerosis, acute disseminated encephalomyelitis (ADEM), traumatic spine injury, autoimmune diseases such as systemic lupus erythematosus, neurosarcoidosis, and Sjögren syndrome, paraneoplastic syndromes, post or para-infectious myelitis including viral, bacterial, fungal and parasitic agents, spinal cord tumor and current COVID-19 infection were considered. Our patient had long ( $\geq 3 \mathrm{vertebral}$ segments) transversal segment involvement leading to bilateral lower limb weakness with no evidence of compression on imaging, and symmetric sensory deficit below specific dermatome accompanied by urinary retention. Based on the Brighton case definition for TM, [8] level 1 diagnostic certainty of TM requires histopathology identification of acute 
cord inflammation, level 2 diagnostic certainty requires the presence of myelopathy symptoms, along with 2 or more of the following indicators:

- $\quad$ Fever up to $38^{\circ} \mathrm{C}$

- $\quad$ CSF pleocytosis $(\mathrm{WBC}>5 / \mu \mathrm{l})$

- Neuroimaging findings demonstrating acute inflammation or demyelination of spinal cord.

Level 3 diagnostic certainty requires the presence of myelopathy symptoms and 1 of the indicators previously mentioned.

Accordingly, our patient was diagnosed with LETM with level 2 diagnostic certainty.

\subsection{Treatment}

The patient was treated with $30 \mathrm{mg} / \mathrm{kg} 3$ times per day Acyclovir until a source of infection was excluded and $1 \mathrm{~g} / \mathrm{day}$ intravenous (IV) methylprednisolone over 5 days. A Foley catheter was inserted for 14 days to relieve her urinary retention. Patient lower limb extremity weakness improved (motor strength 1/5) regained normal function (motor strength 2/5) and sensation of her upper limb. She was discharged home with outpatient physiotherapy.

\subsection{Outcome and follow-up}

After discharge, she had a slow progressive improvement in function and amelioration in her urinary retention. However, her weakness worsened after her third physiotherapy session, so she was readmitted to the hospital and a total dose of $15 \mathrm{~g}$ IV immunoglobulin (IVIG) was administered over 3 days, then an additional $10 \mathrm{~g}$ was administered later on to complete a full dose of $25 \mathrm{~g}$ of IVIG. Although she had significant improvement in her upper limb, patient is still suffering from lower limb weakness and subsequent inability to move in order to complete daily life activity.

\section{Discussion}

As of November $5^{\text {th }}, 2021,7,180,519,949$ doses of COVID-19 vaccines were administered around the world [9]. Following immunization, possible side effects include fever, chills, headache, fatigue, myalgia, arthralgia, and inflammation and pain at the injection site. Serious neurological complications, such as TM, are rare but constitute a major concern, as they can cause physical impairment and lifelong disabilities that necessitate long term care [5]. In transverse myelitis, there is an immune mediated focal inflammatory demyelinating process of the spinal cord resulting in sensory (e.g. paresthesia in the extremities, back pain... ), motor (e.g. limb weakness, paraplegia...), and autonomic (e.g. sphincter dysfunction) symptoms that appear as soon as few hours or after several weeks [10]. In addition, once symptoms begin, they tend to worsen over time. When lesion extends over more than 3 vertebral segments, the condition is referred to as LETM [10].

The lack of multiple sclerosis lesion pattern in the brain MRI, the absence of marked CSF pleocytosis, and the extensive transverse spinal cord lesion, all ruled out multiple sclerosis. In addition, MRI effectively excluded ADEM, tumoral and vascular lesions. There was no signs of optic neuritis and Serum anti-aquaporin 4 antibodies were negative, hence neuromyelitis optica was unlikely. Moreover, concurrent negative serology and sterile CSF excluded the possibility of an infectious origin. The diagnosis of Guillain-Barré syndrome was excluded due to the absence of an albuminocytological dissociation in CSF, and specific EMG features. According to Brighton case definition for TM, [8] we diagnosed the patient with vaccination induced LETM with level 2 diagnostic certainty associated with post-vaccinal sixth nerve palsy. An extensive literature review was conducted to identify published case reports on transverse myelitis induced by SARS-CoV-2 vaccines and findings were tabulated. (Table 2).

In addition to our case, TM occurred post-AstraZeneca, in 7 out of 15 cases and the diagnosis of LETM was made in 8 out of 15 cases. Majority had TM alone, however few papers presented TM in association with palsies, [11,12] optic neuritis, [13] or on top of chronic myelitis [14]. Particularly, our patient suffered from LETM jointly with abducens nerve palsy. The later was only described in one patient who developed esotropia 2 days after receiving COVID-19 vaccine [7]. In addition, our affected subject appeared to be younger than the majority of cases and only 1 study reported TM in a 16 years old child in Saudi Arabia after receiving the second dose of Pfizer-BioNTech vaccine [15]. Onset of symptoms varied between 1 day and 3 weeks. Symptoms presentation of our patient also fell in this range. Similarly to our cases, tetraparesis was also described by Pagenkopf et al [16] and Erdem et al [17]. 
Table 2 Summary of reported case in the literature of transverse myelitis induced by vaccination

\begin{tabular}{|c|c|c|c|c|c|c|c|c|c|}
\hline Author & Country & Diagnosis & $\begin{array}{l}\text { Age/ } \\
\text { gender }\end{array}$ & $\begin{array}{c}\text { Vaccine } \\
\text { type/dos } \\
\text { e }\end{array}$ & Onset & MRI findings & Symptoms & Treatment & Outcome \\
\hline Tahir et al [12] & U.S.A. & $\begin{array}{l}\text { LETM+ } \\
\text { Bell's } \\
\text { palsy }\end{array}$ & $\begin{array}{l}\text { 44years/ } \\
\text { female }\end{array}$ & $\begin{array}{l}\text { Johnson } \\
\text { \&Johnson } \\
\text { / no } \\
\text { infromati } \\
\text { on }\end{array}$ & $\begin{array}{l}10 \\
\text { days }\end{array}$ & $\begin{array}{l}\text { T2 hyper- } \\
\text { intensity at C2- } \\
\text { C3 extending to } \\
\text { upper thoracic } \\
\text { spine }\end{array}$ & $\begin{array}{l}\text { Back pain, paresthesia in } \\
\text { neck and abdomen } \\
\text { Numbness, weakness and } \\
\text { hyperreflexia in the lower } \\
\text { limbs } \\
\text { Urinary retention }\end{array}$ & $\begin{array}{l}\text { IV prednisolone } \\
\text { +plasmapheresis }\end{array}$ & Improved \\
\hline Gao et al [20] & Taiwan & $\begin{array}{l}\text { LETM+ } \\
\text { vitamin } \\
\text { B12 } \\
\text { deficiency }\end{array}$ & $\begin{array}{l}76 \text { years / } \\
\text { female }\end{array}$ & $\begin{array}{l}\text { Moderna/ } \\
1^{\text {st }} \text { dose }\end{array}$ & 2 days & $\begin{array}{l}\text { T2 hyper- } \\
\text { intensity at C2- } \\
\text { C5 with ring } \\
\text { enhancement } \\
\text { at C3 }\end{array}$ & $\begin{array}{l}\text { Right upper and lower limb } \\
\text { and sacral paresthesia and } \\
\text { thermal analgesia, } \\
\text { proprioception sensation } \\
\text { loss below T4 } \\
\text { Gait disturbance, } \\
\text { hyperreflexia in the right } \\
\text { limbs }\end{array}$ & $\begin{array}{l}\text { Pulse IV then oral } \\
\text { methyl } \\
\text { prednisolone+ } \\
\text { Hydroxycobalamine }\end{array}$ & Improved \\
\hline Hsiao et al [11] & Taiwan & $\begin{array}{l}\text { Acute } \\
\text { transverse } \\
\text { myelitis } \\
\text { (ATM)+ } \\
\text { facial } \\
\text { palsy }\end{array}$ & $\begin{array}{l}41 \text { years/ } \\
\text { male }\end{array}$ & $\begin{array}{l}\text { AstraZene } \\
\text { ca/1st } \\
\text { dose }\end{array}$ & $\begin{array}{l}2 \\
\text { weeks }\end{array}$ & $\begin{array}{l}\text { T2 hyper- } \\
\text { intensity at T1- } \\
\text { T6 with cord } \\
\text { enhancement } \\
\text { in early T1 and } \\
\text { post contrast } \\
\text { T1 }\end{array}$ & $\begin{array}{l}\text { Paresthesia below T4, loss } \\
\text { proprioception and } \\
\text { vibration sensation in both } \\
\text { limbs } \\
\begin{array}{l}\text { Lower limb weakness, } \\
\text { clumsiness } \\
\text { hyperreflexia }\end{array}\end{array}$ & $\begin{array}{l}\text { Pulse IV then oral } \\
\text { methyl } \\
\text { prednisolone }\end{array}$ & Improved \\
\hline Tan et al [21] & Malaysia & LETM & $\begin{array}{l}25 \\
\text { years/fe } \\
\text { male }\end{array}$ & $\begin{array}{l}\text { AstraZene } \\
\text { ca/1 } 1^{\text {st }} \\
\text { dose }\end{array}$ & 5 days & $\begin{array}{l}\text { T2 hyper- } \\
\text { intensity at T3- } \\
\text { T5, T7-T8 and } \\
\text { T11-L1 with } \\
\text { variable cord } \\
\text { enhancement }\end{array}$ & $\begin{array}{l}\text { Numbness and allodynia } \\
\text { below T8 } \\
\text { Progressive bilateral lower } \\
\text { limb weakness then } \\
\text { inability to walk, } \\
\text { hyperreflexia } \\
\text { Urinary retention }\end{array}$ & $\begin{array}{l}\text { IV methyl } \\
\text { prednisolone }\end{array}$ & Improved \\
\hline
\end{tabular}


World Journal of Advanced Research and Reviews, 2021, 12(02), 526-538

\begin{tabular}{|c|c|c|c|c|c|c|c|c|c|}
\hline $\begin{array}{l}\text { Mclean et al } \\
{[18]}\end{array}$ & U.S.A. & LETM & $\begin{array}{l}69 \\
\text { years } / \mathrm{fe} \\
\text { male }\end{array}$ & $\begin{array}{l}\text { Pfizer- } \\
\text { BioNTech } \\
/ 1^{\text {st }} \text { dose }\end{array}$ & 2 days & $\begin{array}{l}\text { T2 hyper- } \\
\text { intensity at C3- } \\
\text { C4 to T2-T3 } \\
\text { involving the } \\
\text { anterior and } \\
\text { mid cord }\end{array}$ & $\begin{array}{l}\text { Upper and lower limb } \\
\text { paresthesia } \\
\text { Upper and lower extremity } \\
\text { weakness, then inability to } \\
\text { walk } \\
\text { Urinary urgency and } \\
\text { incontinence (on follow- } \\
\text { up) }\end{array}$ & $\begin{array}{l}\text { IV methyl } \\
\text { prednisolone }\end{array}$ & Improved \\
\hline Khan et al [22] & India & ATM & $\begin{array}{l}67 \\
\text { years/fe } \\
\text { male }\end{array}$ & $\begin{array}{l}\text { Moderna } \\
/ 1^{\text {st }} \text { dose }\end{array}$ & 1 day & $\begin{array}{l}\text { Stir hyper- } \\
\text { intensity at C1- } \\
\text { C3 with patchy } \\
\text { post contrast } \\
\text { enhancement } \\
\text { on T1 }\end{array}$ & $\begin{array}{l}\text { Paresthesia right lower } \\
\text { limb, loss of vibration } \\
\text { sensation up to the ankle } \\
\text { Bilateral upper and lower } \\
\text { extremity weakness, } \\
\text { hyperreflexia }\end{array}$ & $\begin{array}{l}\text { IV } \\
\text { methylprednisolone } \\
\text { +plasmapheresis }\end{array}$ & Improved \\
\hline $\begin{array}{l}\text { Albokhari et al } \\
\text { [15] }\end{array}$ & $\begin{array}{l}\text { Saudi } \\
\text { Arabia }\end{array}$ & ATM & $\begin{array}{l}16 \\
\text { years/fe } \\
\text { male }\end{array}$ & $\begin{array}{l}\text { Pfizer- } \\
\text { BioNTech } \\
/ 2^{\text {nd }} \text { dose }\end{array}$ & 2 days & $\begin{array}{l}\text { T2 hyper- } \\
\text { intensity at } \\
\text { cervical and } \\
\text { thoracic spine }\end{array}$ & $\begin{array}{l}\text { Lower extremity } \\
\text { numbness, decrease } \\
\text { sensation to fine and pain } \\
\text { stimuli } \\
\text { Lower extremity then } \\
\text { upper extremity weakness, } \\
\text { hyperreflexia }\end{array}$ & $\begin{array}{l}\text { IV } \\
\text { methylprednisolone }\end{array}$ & Improved \\
\hline Alshararni [14] & $\begin{array}{l}\text { Saudi } \\
\text { Arabia }\end{array}$ & $\begin{array}{l}\text { Acute on } \\
\text { top of } \\
\text { chronic } \\
\text { TM }\end{array}$ & $\begin{array}{l}38 \\
\text { years/ma } \\
\text { le }\end{array}$ & $\begin{array}{l}\text { Pfizer- } \\
\text { BioNTech } \\
/ 1^{\text {st }} \text { dose }\end{array}$ & 2 days & $\begin{array}{l}\text { Sclerotic cord } \\
\text { margin, } \\
\text { cord } \\
\text { enhancement } \\
\text { at T11-T12 } \\
\text { with hypo- } \\
\text { intensity on T1 } \\
\text { and hyper- } \\
\text { intensity on T2 } \\
\text { and Stir }\end{array}$ & $\begin{array}{l}\text { Lower limb pain } \\
\text { Lower limb weakness then } \\
\text { paraplegia, }\end{array}$ & No infromation & Improved \\
\hline
\end{tabular}


World Journal of Advanced Research and Reviews, 2021, 12(02), 526-538

\begin{tabular}{|c|c|c|c|c|c|c|c|c|c|}
\hline $\begin{array}{l}\text { Malhotra et al } \\
{[23]}\end{array}$ & India & ATM & $\begin{array}{l}36 \\
\text { years/ma } \\
\text { le }\end{array}$ & $\begin{array}{l}\text { AstraZene } \\
\text { ca/ } 1^{\text {st }} \\
\text { dose }\end{array}$ & 8 days & $\begin{array}{l}\text { T2 hyper- } \\
\text { intensity at C6- } \\
\text { C7 in the dorsal } \\
\text { aspect of the } \\
\text { cord, and } \\
\text { moderate } \\
\text { peripheral } \\
\text { enhancement } \\
\text { on T1 }\end{array}$ & $\begin{array}{l}\text { Bilateral lower limb } \\
\text { abnormal sensation } \\
\text { ascending to the trunk } \\
\text { Hyperreflexia }\end{array}$ & $\begin{array}{l}\text { Oral then IV } \\
\text { methylprednisolone }\end{array}$ & Improved \\
\hline $\begin{array}{l}\text { Pagenkopf et al } \\
\text { [16] }\end{array}$ & Germany & LETM & $\begin{array}{l}45 \\
\text { years/ma } \\
\text { le }\end{array}$ & $\begin{array}{l}\text { AstraZene } \\
\text { ca/ } 1^{\text {st }} \\
\text { dose }\end{array}$ & $\begin{array}{l}11 \\
\text { days }\end{array}$ & $\begin{array}{l}\mathrm{T} 2 \\
\text { hyperintensity } \\
\text { from C3 to T2 } \\
\text { with wide } \\
\text { involvement of } \\
\text { the cord }\end{array}$ & $\begin{array}{l}\text { Thoracic back pain, } \\
\text { sensory level at T9 } \\
\text { Generalized weakness, } \\
\text { followed by acute flaccid } \\
\text { tetraparesis } \\
\text { Urinary retention }\end{array}$ & $\begin{array}{l}\text { Pulse IV then oral } \\
\text { methyl } \\
\text { prednisolone }\end{array}$ & Improved \\
\hline $\begin{array}{l}\text { Erdem et al } \\
{[17]}\end{array}$ & Turkey & LETM & $\begin{array}{l}78 \\
\text { years } / \mathrm{fe} \\
\text { male }\end{array}$ & $\begin{array}{l}\text { Sinovac- } \\
\text { Coronavac } \\
\text { /no } \\
\text { informati } \\
\text { on }\end{array}$ & $\begin{array}{l}3 \\
\text { weeks }\end{array}$ & $\begin{array}{l}\text { C1-T3 spinal } \\
\text { cord } \\
\text { involvement }\end{array}$ & $\begin{array}{l}\text { Paresthesia upper limb } \\
\text { Tetraparesis } \\
\text { Urinary retention }\end{array}$ & No information & $\begin{array}{l}\text { No } \\
\text { information }\end{array}$ \\
\hline $\begin{array}{l}\text { Notghi et al } \\
{[19]}\end{array}$ & U.K. & LETM & $\begin{array}{l}58 \\
\text { years/ma } \\
\text { le }\end{array}$ & $\begin{array}{l}\text { AstraZene } \\
\text { ca/1 } 1^{\text {st }} \\
\text { dose }\end{array}$ & 7 days & $\begin{array}{l}\text { T2 and Stir } \\
\text { hyper-intensity } \\
\text { from T2 to T10 } \\
\text { with enhancing } \\
\text { myelitis at T3 } \\
\text { and T9/T10 } \\
\text { levels }\end{array}$ & $\begin{array}{l}\text { Progressive lower limb } \\
\text { numbness, allodynia } \\
\text { extending to the chest, } \\
\text { hyperesthesia below T7 } \\
\text { All four limb hyperreflexia } \\
\text { Urinary incontinence }\end{array}$ & $\begin{array}{l}\text { IV } \\
\text { methylprednisolone } \\
\text { then oral } \\
\text { prednisolone+ } \\
\text { plasmapheresis }\end{array}$ & $\begin{array}{l}\text { Improveme } \\
\text { nt }\end{array}$ \\
\hline $\begin{array}{l}\text { Helmshen et al } \\
{[13]}\end{array}$ & Germany & $\begin{array}{l}\text { LETM } \\
\text { with optic } \\
\text { neuritis in } \\
\text { patient } \\
\text { with } \\
\text { relapsing- } \\
\text { remitting }\end{array}$ & $\begin{array}{l}40 \\
\text { years } / \mathrm{fe} \\
\text { male }\end{array}$ & $\begin{array}{l}\text { AstraZene } \\
\text { ca/1 } 1^{\text {st }} \\
\text { dose }\end{array}$ & $\begin{array}{l}2 \\
\text { weeks }\end{array}$ & $\begin{array}{l}\text { T2 increased } \\
\text { longitudinal } \\
\text { centrally } \\
\text { located signal } \\
\text { intensity } \\
\text { through the } \\
\text { thoracic cord }\end{array}$ & $\begin{array}{l}\text { Binocular blindness } \\
\text { Back pain, numbness in } \\
\text { lower extremity, sensory } \\
\text { deficit below T5 } \\
\text { Weakness in lower } \\
\text { extremity progressed to } \\
\text { inability to walk and then }\end{array}$ & $\begin{array}{l}\text { Steroids } \\
\text { plasmapheresis+ } \\
\text { immune-adsorption }\end{array}$ & $\begin{array}{l}\text { Partial } \\
\text { improveme } \\
\text { nt }\end{array}$ \\
\hline
\end{tabular}


World Journal of Advanced Research and Reviews, 2021, 12(02), 526-538

\begin{tabular}{|c|c|c|c|c|c|c|c|c|c|}
\hline & & $\begin{array}{l}\text { multiple } \\
\text { sclerosis }\end{array}$ & & & & $\begin{array}{l}\text { reaching } \quad \text { T7- } \\
\text { T10. }\end{array}$ & $\begin{array}{l}\text { paraplegia, absent tendon } \\
\text { reflex } \\
\text { Incontinence }\end{array}$ & & \\
\hline $\begin{array}{l}\text { Vegezzi et al } \\
{[24]}\end{array}$ & Italy & ATM & $\begin{array}{l}44 \\
\text { years/fe } \\
\text { male }\end{array}$ & $\begin{array}{l}\text { AstraZene } \\
\text { ca/1 } 1^{\text {st }} \\
\text { dose }\end{array}$ & 4 days & $\begin{array}{l}\text { T2 hyper- } \\
\text { intensity at T7- } \\
\text { T8 posterior } \\
\text { cord with } \\
\text { enhancement } \\
\text { on post } \\
\text { contrast T1 } \\
\text { T2 hyper- } \\
\text { intensity at } \\
\text { T10-T11 }\end{array}$ & $\begin{array}{l}\text { Bilateral lower limb } \\
\text { ascending paresthesia, } \\
\text { reduced sensation lower } \\
\text { back and during } \\
\text { micturition, reduced } \\
\text { pinprick and light touch } \\
\text { sensation up to the ankles } \\
\text { Brisk deep tendon reflex in } \\
\text { lower limb }\end{array}$ & $\begin{array}{l}\text { IV then oral } \\
\text { methylprednisolone }\end{array}$ & Improved \\
\hline $\begin{array}{l}\text { Fitzsimmons } \\
\text { and Nance et } \\
\text { al [25] }\end{array}$ & USA & ATM & $\begin{array}{l}63 \text { years/ } \\
\text { male }\end{array}$ & $\begin{array}{l}\text { Moderna/ } \\
2^{\text {nd }} \text { dose }\end{array}$ & 1 day & $\begin{array}{l}\text { T2 hyper- } \\
\text { intensity at the } \\
\text { distal spinal } \\
\text { cord and conus }\end{array}$ & $\begin{array}{lr}\begin{array}{l}\text { Lower back } \\
\text { extremity pain, lower } \\
\text { paresthesia }\end{array} & \begin{array}{l}\text { pain } \\
\text { Inability to walk }\end{array} \\
\begin{array}{l}\text { Urinary } \\
\text { involuntary } \\
\text { constipation }\end{array} & \\
& \text { retention, } \\
& \end{array}$ & $\begin{array}{l}\text { IVIG+IV then oral } \\
\text { methylprednisolone }\end{array}$ & Improved \\
\hline
\end{tabular}


Contrary to our case with urinary retention, urinary incontinence was observed in 3 reports $[13,18,19]$. This might be attributed to a detrusor hyperreflexia resulting in urge incontinence, or to an overflow incontinence precipitated by low spinal cord lesion. Comparably, coinciding cervical and thoracic lesions were also reported in several studies. [15-18] Till date, there is no clearly defined consensus regarding the gold standard treatment of vaccine induced LETM, in accordance with the literature, we treated our patient with IV methylprednisolone. Upon clinic deterioration or refractory cases, plasmapheresis was performed in majority of cases $[12,19,20]$. Due to lack of albumin in our institution, patient received IVIG instead, this therapeutic option was also adopted by Fitzsimmons and Nance et al [25].

The exact mechanism that clarify the causal relation between SARS-CoV-2 and TM is still unknown. We can postulate that autoimmunity resulting in demyelination of the spinal cord in TM could be due to a molecule mimicry process since, vaccine particle similarly to infectious agents could share similar antigen with the host cells. This might trigger several immune reactions that targets the spinal cord [3].

\section{Conclusion}

Here, we discussed the case of LETM with sixth nerve palsy that occurred shortly after first dose of ChAdOx1 nCov-19 vaccine. The diagnosis was made by MRI and temporal correlation between symptoms and vaccine administration. Blood and CSF work-up were performed to exclude other etiologies. Our report might increase the hesitancy on vaccination for the public population, however we should bear in mind the significant benefit of immunization for personal and collective immunity to fight this pandemic. Furthermore, identifying similar rare adverse events is only possible in post-marketing surveillance, and reporting them should be a global scientific priority to better communicate the risks and benefits of vaccines.

\section{Compliance with ethical standards}

\section{Acknowledgments}

We would like to thank Dr. Ahmad Takech for MRI interpretations, and Secours Populaire Libanais health workers for their kind cooperation.

\section{Disclosure of conflict of interest}

The authors declare no conflict of interest.

\section{Statement of informed consent}

Written informed consent was obtained from the patient for the publication of this paper.

\section{Abbreviations}

ADEM: acute disseminated encephalomyelitis

ChAdOx1 nCov-19 vaccine: Chimpanzee Adenovirus-vector vaccine

COVID-19: Coronavirus Disease 2019

CSF:vCerebrospinal fluid

EMG: Electromyography

IV: Intravenous

IVIG: Intravenous Immunoglobulin

LETM: Longitudinal Extensive Transverse Myelitis

MMR: Measles, Mumps, Rubella

MTB: Mycobacterium Tuberculosis

MRI: Magnetic Resonance Imaging

NTM: Non Tuberculous Mycobacterium

RT-PCR: Real Time Polymerase Chain Reaction

SARS-CoV2: Severe Acute Respiratory Virus 2

TM: Transverse Myelitis 


\section{References}

[1] West TW, Hess C CB. Acute transverse myelitis: demyelinating, inflammatory, and infectious myelopathies. Seminars in neurology. 2012; 32(2): 97-113.

[2] Bhat A, Naguwa S, Cheema GGM. The epidemiology of transverse myelitis.Autoimmunity reviews. 2010; 9: A3959.

[3] Agmon-Levin N, Kivity S, Szyper-Kravitz MSY. Transverse myelitis and vaccines: a multi-analysis. Lupus. 2009;18:1198-204.

[4] Goss AL, Samudralwar RD, Das RR NA. ANA Investigates: Neurological Complications of COVID-19 Vaccines.Annals of Neurology. 2021; 89: 856-7.

[5] Garg RK PV. Spectrum of neurological complications following COVID-19 vaccination.Neurological Sciences. $2021 ; 1-38$.

[6] Elder C, Hainline C, Galetta SL, Balcer LJ RJ. Isolated Abducens Nerve Palsy: Update on Evaluation and Diagnosis.Current Neurology and Neuroscience Reports. 2016; 16: 69.

[7] Reyes-Capo DP, Stevens SM CK. Acute abducens nerve palsy following COVID-19 vaccination. Journal of AAPOS : the official publication of the American Association for Pediatric Ophthalmology and Strabismus. 2021; S10918531.

[8] Sejvar JJ, Kohl KS, Bilynsky R, Blumberg D, Cvetkovich T, Galama J, Gidudu J, Katikaneni L, Khuri-Bulos N, Oleske J, Tapiainen T WM. Brighton Collaboration Encephalitis Working Group.Encephalitis, myelitis, and acute disseminated encephalomyelitis (ADEM): case definitions and guidelines for collection, analysis, and presentation of immunization safety data. Vaccine. 2007; 25(31): 5771-92.

[9] The Center for Systems Science and Engineering (CSSE) at John Hopkins University.COVID-19 Dashboard [Internet].Baltimore: Johns Hopkins University; [cited 2021 Nov 5].

[10] West TW. Transverse myelitis--a review of the presentation, diagnosis, and initial management. Discovery Medicine. 2013; 16: 167-77.

[11] Hsiao YT, Tsai MJ, Chen YH HC. Acute Transverse Myelitis after COVID-19 Vaccination. Medicina. $2021 ; 57: 1010$.

[12] Tahir N, Koorapati G, Prasad S, Jeelani HM, Sherchan R, Shrestha J SM. SARS-CoV-2 Vaccination-Induced Transverse Myelitis.Cureus. 2021; 13: e16624.

[13] Helmchen C, Buttler GM, Markewitz R, Hummel K, Wiendl H BT. Acute bilateral optic/chiasm neuritis with longitudinal extensive transverse myelitis in longstanding stable multiple sclerosis following vector-based vaccination against the SARS-CoV-2. Journal of Neurology. 2021;15: 1-6.

[14] Alshararni A. Acute Transverse Myelitis Associated with COVID-19 vaccine: A Case Report. International Journal of Research in Pharmaceutical Sciences. 2021; 12: 2083-7.

[15] Ammar Albokhari , Abdulrhman Alsawas, Mohammad Adnan, Abdulaziz Alasmari, Aljuhani S, Almejalli M, Kedah H. Acute inflammatory Transverse Myelitis post Pfizer-BioNTech-COVID-19 vaccine in 16-year-old.ScienceOpen Preprints. 2021.

[16] Pagenkopf C SM. A case of longitudinally extensive transverse myelitis following vaccination against Covid-19. Journal of Neuroimmunology. 2021; 358: 577606.

[17] Erdem NŞ, Demirci S, Özel T, Mamadova K, Karaali K, Çelik HT, Uslu FI ÖS. Acute transverse myelitis after inactivated COVID-19 vaccine. Ideggyogy Sz. 2021; 74(7-08): 273-276.

[18] McLean PTL. Transverse myelitis 48 hours after the administration of an mRNA COVID 19 vaccine. Neuroimmunology Reports. 2021; 1: 100019.

[19] Notghi AA, Atley JSM. Lessons of the month 1: Longitudinal extensive transverse myelitis following AstraZeneca COVID-19 vaccination. Clinical medicine (London, England). 2021; 21: e535-8.

[20] Gao JJ, Tseng HP, Lin CL, Shiu JS, Lee MH LC. Acute Transverse Myelitis Following COVID-19 Vaccination. Vaccines. 2021; 9: 1008. 
[21] Tan WY, Yusof Khan AHK, Mohd Yaakob MN, Abdul Rashid AM, Loh WC, Baharin J, Ibrahim A, Ismail MR, Inche Mat LN, Wan Sulaiman WA, Basri H HF. Longitudinal extensive transverse myelitis following ChAdOx1 nCOV-19 vaccine: a case report. BMC Neurology. 2021; 21: 395.

[22] Khan E, Shrestha AK, Colantonio MA, Liberio RN SS. Acute transverse myelitis following SARS-CoV-2 vaccination: a case report and review of literature. Journal of Neurology. 2021; 5: 1-5.

[23] Malhotra SH, Gupta P, Prabhu V, Garg RK, Dandu H A V. COVID-19 vaccination-associated myelitis.QJM: An International Journal of Medicine 2021: 1-3.

[24] Vegezzi E, Ravaglia S, Buongarzone G, Bini P, Diamanti L, Gastaldi M, Prunetti P, Rognone E ME. Acute myelitis and ChAdOx1 nCoV-19 vaccine: Casual or causal association? Journal of Neuroimmunology. 2021; 359: 577686.

[25] Fitzsimmons WNC. Sudden Onset of Myelitis after COVID-19 Vaccination: An Under-Recognized Severe Rare Adverse Event. 2021. 